\title{
Descriptive Online Survey: Knowledge, Attitudes, and Anxiety During the Period of Pandemic COVID-19 in Indonesia
}

\author{
Agung Sutriyawan ${ }^{1}$, Hairil Akbar ${ }^{2}$, Fibrianti $^{3}$, Intan Pertiwi ${ }^{4}$, Ucu W. Somantri ${ }^{5}$, Lezi Y. Sari ${ }^{6}$ \\ ${ }^{1}$ Research Scholar, Bachelor Programme Public Health, Bhakti Kencana University, ${ }^{2}$ Research Scholar, Graha \\ Medika Institute of Health Science, ${ }^{3}$ Research Scholar, Hamzar Institute of Health Science, ${ }^{4}$ Research Scholar, \\ Infectious Disease Hospital Prof. Dr. Sulianti Saroso, ${ }^{5}$ Research Scholar, Mathla ul Anwar University, ${ }^{6}$ Research \\ Scholar, Dehasen University of Bengkulu
}

\begin{abstract}
Background: The Government provides directives related to the prevention of cases spread, but the number of cases still shows improvement. Community knowledge and attitudes influence the level of compliance with the Government's recommended COVID-19 deployment precautions.
\end{abstract}

Objectives: Assess knowledge, attitudes, and anxiety during the COVID-19 period.

Method: This is a quantitative descriptive study, sampling techniques using Snowball. Questionnaires have four parts, social-demographic, knowledge, attitude, and anxiety during the pandemic. Online questionnaires were developed using Google forms. Questionnaire link sent via email, Whats App, Facebook. Variables are summarized into frequencies and percentages using SPSS version 25.

Results: Total (61.3\%) The respondent knows how to spread COVID-19, (97.4\%) and (95.3\%) Know COVID-19 is more dangerous for elderly and people have chronic diseases, (95.1\%) Know the handwashing is a preventive effort, almost all of the participants agreed on hand washing, hand sanitizer, using a mask, (92\%) Participants agreed to the screening COVID-19, (93\%) Participants are willing to follow the Government's recommendation, (60\%) Participants felt paranoid, (83\%) Participants are always worried for themselves and those closest to you.

Conclusion: This study resulted in respondents having demonstrated good knowledge, positive attitudes, and feeling anxious during the COVID-19 pandemic

Keywords: COVID-19, knowledge, attitude, anxiety.

\section{Introduction}

Coronavirus disease Pandemic 2019 (COVID-19) is a problem that is happening in more than 200 countries in the world. COVID-19 has been identified as the cause of infectious respiratory disease outbreak in Wuhan,

\footnotetext{
Corresponding Author: Agung Sutriyawan

Research Scholar, Bachelor Programme Public Health, Bhakti Kencana University e-mail: agung.epid@gmail.com
}

China. ${ }^{1}$ The COVID-19 is highly contagious as most people do not have immunity against this new virus. Currently, COVID-19 attempts are performed only on the treatment of symptoms, treatment, and prevention of complications, but there have not been any medications that can cure this disease. Therefore, the best strategies to keep prevention such as keeping social distances or wearing masks may help us to prevent infections. ${ }^{2}$ The governmental action of closing public services causes the collapse of the industry to negatively impact the economy. ${ }^{3}$

The spread of COVID-19 caused confusion, anxiety, and fear among the general public. A variety of research 
on COVID-19, many facts are constantly changing and many myths are not prevalent in the general population regarding the prevention and management of infections. This is sometimes very annoying for certain individuals. ${ }^{4}$ The absence of appropriate protective measures is the main cause of concern among common society. At the community level, there is distrust of others in the spread of disease and the role of government in tackling the plague. Especially in countries like Indonesia which is a populated country without strong health infrastructure, it is the cause of concern. Some levels of panic also appear in public due to the unavailability of basic protective measures.

COVID-19 was first reported in Indonesia on February 2, 2020, until today it continues to increase. Governments, media, physicians, researchers, celebrities, police and other community stakeholders urge communities to avoid public gatherings such as sports, religious ceremonies, family events, meetings and classes in schools, this is done to prevent the spread of Coronavirus infections. ${ }^{4}$ Disbelief in the spread of disease and the role of the government in tackling the plague so that the spread of COVID-19 in Indonesia is difficult to overcome. To comply with the Government's recommendation, the public requires knowledge of the spread, the title, prevention of COVID-19. Facts in the field still many people ignore the importance of social distance due to attitude problems. Anxiety and community concerns generally affect every individual. Recent evidence suggests that individuals who are in isolation and quarantine experience anxiety, anger, confusion. ${ }^{5}$ The knowledge and attitude of society largely affect the level of adherence to the prevention of disease spread that has been recommended by the Government. Therefore, it is important to study these domains in the Indonesian population. Based on the relevance of all of the above factors, researchers aim to assess the perceived knowledge, attitudes, and anxieties during the COVID-19 pandemic in Indonesia.

\section{Material and Method}

The type of research used is quantitative descriptive. This approach was done to see a clear and accurate picture of the knowledge, attitudes, and anxieties during the pandemic COVID-19 period in the Indonesian population. Sampling techniques using Snowball. A semistructured online questionnaire was developed using the Google form, with the consent form also available. Questionnaire links are sent via email, Whats App,
Facebook, or any other social media to the respondent. The questionnaire contains the characteristics of socialdemographic, knowledge, attitudes, and anxiety in sequence, which the respondents must answer. This study is an online study, participants who can participate in this research if they have a social media account and have access to the Internet. The age of participants in this study is more than 18 years old, able to understand Bahasa Indonesia, and willing to approve respondents. Data collection started on 16 June 2020 hours 13.00 WIB and closed on 23 June 2020 at 12.00 WIB.

The questionnaire consists of 9 questions about knowledge covering the way of transmission, symptoms, prevention, and treatment of COVID-19. The questionnaire attitude during the pandemic contains 15 question items that are graded with a scale Likert 5 points, namely: very disagree, disagree, hesitate, agree, and strongly agree. Anxiety during a pandemic associated with a COVID-19 infection has 17 question items, rated using a Likert scale of 4 points, namely: never, sometimes, often and always. The analysis in this study uses descriptive statistics using SPSS version 25 . Variables are summarized into frequency and percentage distribution based on the question item given to the respondent

\section{Findings:}

Table 1. Socio-Demographic of the Participants

$$
(\mathbf{n}=\mathbf{1 0 5 1})
$$

\begin{tabular}{|l|c|c|}
\hline Socio-demographic Characteristics & Frequency & \% \\
\hline Age (years) & 163 & 15,5 \\
\hline$\leq 20$ & 511 & 48,6 \\
\hline $21-30$ & 277 & 26,4 \\
\hline $31-40$ & 67 & 6,4 \\
\hline $41-50$ & 28 & 2,7 \\
\hline $51-60$ & 5 & 0,5 \\
\hline$>60$ & & \\
\hline Gender & 319 & 30,4 \\
\hline Male & 732 & 69,6 \\
\hline Women & & \\
\hline Education & 2 & 0,2 \\
\hline No school & 2 & 0,2 \\
\hline Elementary school & 3 & 0,3 \\
\hline Middle School & 262 & 24,9 \\
\hline High school & 782 & 74,4 \\
\hline College & &
\end{tabular}




\begin{tabular}{|l|c|c|}
\hline Socio-demographic Characteristics & Frequency & $\%$ \\
\hline Profession & 174 & 16,6 \\
\hline Government employees & 383 & 36,4 \\
\hline General employees & 95 & 9,0 \\
\hline Entrepreneur & 54 & 5,1 \\
\hline Housewives & 310 & 29,5 \\
\hline Student & 21 & 2,0 \\
\hline Labor & 14 & 1,3 \\
\hline Not working & \multicolumn{2}{|l|}{} \\
\hline Agama & 894 & 85,1 \\
\hline Islam & 136 & 12,9 \\
\hline Christian & 17 & 1,6 \\
\hline Hindu & 3 & 0,3 \\
\hline Buddhist & 1 & 0,1 \\
\hline Confucius & &
\end{tabular}

Source: Primary Data, 2020

The characteristics of socio-demographic participants are shown in table 1. Among the participants who responded, 511 (48.6\%) 21 - 30 years of age group, 732 (69.6\%) Female gender, 782 (74.4\%) College, 383 (36.4\%) Working as a private employee, 894 (85.1\%) Islamic faith.

Table 2. Knowledge of COVID-19 among Research Participants $(n=1051)$

\begin{tabular}{|l|c|c|}
\hline Knowledge Items & Frekuensi & $\%$ \\
\hline 1. COVID-19 spreads through & 116 & 11,0 \\
\hline a. Touch & 287 & 27,3 \\
\hline b. Sneezing & 4 & 0,4 \\
\hline c. Kissing & 644 & 61,3 \\
\hline $\begin{array}{l}\text { d. answered everything (touch, } \\
\text { sneezing, kissing) }\end{array}$ & 983 & 93,5 \\
\hline $\begin{array}{l}\text { 2. COVID-19 can be transmitted from people without } \\
\text { symptoms }\end{array}$ & 41 & 3,9 \\
\hline a. Yes & 27 & 2,6 \\
\hline b. Not & 422 & 40,2 \\
\hline c. Do not know & 365 & 34,7 \\
\hline 3. Pets in the House can transmit COVID-19 \\
\hline a. Yes & 264 & 25,1 \\
\hline b. Not & 1024 & 97,4 \\
\hline c. Do not know & 12 & 1,1 \\
\hline 4. COVID-19 more dangerous for elderly & 1,4 \\
\hline a. Yes & \multicolumn{2}{|c|}{} \\
\hline b. Not & \multicolumn{2}{|c|}{} \\
\hline c. Do not know & \multicolumn{2}{|c|}{} \\
\hline
\end{tabular}

\begin{tabular}{|c|c|c|}
\hline Knowledge Items & Frekuensi & $\%$ \\
\hline \multicolumn{3}{|c|}{$\begin{array}{l}\text { 5. COVID-19 is more dangerous in people who have } \\
\text { chronic diseases }\end{array}$} \\
\hline a. Yes & 1002 & 95,3 \\
\hline b. Not & 12 & 1,1 \\
\hline c. Do not know & 37 & 3,5 \\
\hline \multicolumn{3}{|l|}{ 6. Symptoms } \\
\hline \multicolumn{3}{|l|}{ Fever } \\
\hline a. Yes & 836 & 79,5 \\
\hline b. Not & 215 & 20,5 \\
\hline \multicolumn{3}{|l|}{ Headaches } \\
\hline a. Yes & 325 & 30,9 \\
\hline b. Not & 726 & 69,1 \\
\hline \multicolumn{3}{|l|}{ Cough } \\
\hline a. Yes & 708 & 67,4 \\
\hline b. Not & 343 & 32,6 \\
\hline \multicolumn{3}{|l|}{ Sore throat } \\
\hline a. Yes & 665 & 63,3 \\
\hline b. Not & 386 & 36,7 \\
\hline \multicolumn{3}{|l|}{ Fatigue } \\
\hline a. Yes & 299 & 28,4 \\
\hline b. Not & 752 & 71,6 \\
\hline \multicolumn{3}{|c|}{ Difficulty breathing } \\
\hline a. Yes & 784 & 74,6 \\
\hline b. Not & 267 & 25,4 \\
\hline \multicolumn{3}{|l|}{ Chest Pain } \\
\hline a. Yes & 177 & 16,8 \\
\hline b. Not & 874 & 83,2 \\
\hline \multicolumn{3}{|c|}{$\begin{array}{l}\text { 7. Isolation of a person who has symptoms COVID-19 can } \\
\text { stop the spread of COVID-19? }\end{array}$} \\
\hline a. Yes & 1000 & 95,1 \\
\hline b. Not & 24 & 2,3 \\
\hline c. Do not know & 27 & 2,6 \\
\hline \multicolumn{3}{|c|}{$\begin{array}{l}\text { 8. Frequent hand washing can stop } \\
\text { the spread of COVID-19? }\end{array}$} \\
\hline a. Yes & 999 & 95,1 \\
\hline b. Not & 30 & 2,9 \\
\hline c. Do not know & 22 & 2,1 \\
\hline \multicolumn{3}{|c|}{ 9. Antibiotics can treat COVID-19 } \\
\hline a. Yes & 251 & 23,9 \\
\hline b. Not & 499 & 47,5 \\
\hline c. Do not know & 301 & 28,6 \\
\hline
\end{tabular}

Source: Primary Data, 2020

Knowledge among study participants on COVID-19 is described in Table 2. The majority is $644(61.3 \%)$ Virus 
COVID-19 spreads through touch, sneezing and kissing, 983 (93.5\%), 1024 (97.4\%) Know COVID-19 more dangerous for elderly, 1002 (95.3\%) Know COVID-19 is more dangerous in people who have chronic diseases,
$1000(95.1 \%)$ Know the isolation of a person who has symptoms COVID-19 can stop the spread of COVID-19, and 999 (95.1\%) Know often hand washing can stop the spread of COVID-19.

Table 3. Attitudes About COVID-19 among Participants Research $(n=1051)$

\begin{tabular}{|c|c|c|c|}
\hline \multicolumn{2}{|r|}{ Attitude Items } & \multicolumn{2}{|c|}{$\begin{array}{l}\text { Responses that answered agree } \\
\text { and strongly agree }(\mathrm{N}=1051)\end{array}$} \\
\hline & & $\mathbf{F}$ & $\%$ \\
\hline 1 & When I meet friends, I always greet them without shaking hands & 908 & 86,4 \\
\hline 2 & When I meet my friends and colleagues, I always welcome them without hugging & 956 & 91,0 \\
\hline 3 & I wash my hands using soap or hand sanitizer regularly & 986 & 93,8 \\
\hline 4 & I usually use masks to protect myself from the risk of contracting COVID-19 & 1027 & 97,7 \\
\hline 5 & If I have any of the symptoms associated with COVID-19, I will tell the health worker & 957 & 91,1 \\
\hline 6 & $\begin{array}{l}\text { If I make a contact or interaction with the infected COVID-19, I am willing to be in } \\
\text { isolation at home within a certain period until it proves that I am not infected with } \\
\text { COVID-19 }\end{array}$ & 1014 & 96,5 \\
\hline 7 & $\begin{array}{l}\text { If I make a contact or interaction with the infected COVID-19, I was willing to be } \\
\text { isolated in the hospital within a certain period until it proved that I was not infected } \\
\text { with COVID-19 }\end{array}$ & 947 & 90,1 \\
\hline 8 & If there is a laboratory test available to detect the COVID-19, I am willing to do so & 972 & 92,5 \\
\hline 9 & If there is a vaccine available for COVID-19, I am willing to be vaccinated & 902 & 85,8 \\
\hline 10 & I usually follow the latest updates or news about the spread of COVID-19 in my country & 902 & 85,8 \\
\hline 11 & $\begin{array}{l}\text { I usually follow the latest updates or news about the spread of Covid-19 around the } \\
\text { world }\end{array}$ & 752 & 71,6 \\
\hline 12 & $\begin{array}{l}\text { If the counseling is held about the COVID-19 in the region where I live, I will follow } \\
\text { him }\end{array}$ & 634 & 60,3 \\
\hline 13 & $\begin{array}{l}\text { If it is as smooth or a brochure that includes information about COVID-19, I will read it } \\
\text { and follow the instructions described therein }\end{array}$ & 912 & 86,8 \\
\hline 14 & $\begin{array}{l}\text { I am willing to follow the Government's recommendation regarding the prevention of } \\
\text { COVID-19 transmission }\end{array}$ & 987 & 93,9 \\
\hline 15 & I am willing to buy COVID-19 preventive equipment such as masks and hand sanitizer & 983 & 93,5 \\
\hline
\end{tabular}

Source: Primary Data, 2020

Preventive measures to limit the spread of COVID-19 and their responses are presented in table 3. The majority of participants agreed when meeting friends or colleagues did not shake hands or embraced. Almost all of the participants said they agreed to wash their hands using soap or hand sanitizer regularly and use masks to protect themselves from the transmission of COVID-19. Most study participants agreed in isolation at home or in the hospital if they made contact with the COVID-19 or infected people. Approximately $92 \%$ of participants agreed to the screening for COVID-19. The results of the study were obtained about $93 \%$ of the participants were willing to follow the Government's recommendation regarding the prevention of COVID-19 transmission and willing to purchase COVID-19 preventive equipment such as masks and hand sanitizers. 
Table 4: Anxiety about COVID-19 among Participants Research $(n=1051)$

\begin{tabular}{|c|c|c|c|}
\hline \multicolumn{2}{|r|}{ During the COVID-19 Pandemic } & \multicolumn{2}{|c|}{$\begin{array}{l}\text { Responses that feel anxious } \\
\text { (often and always) }(\mathrm{N}=\mathbf{1 0 5 1})\end{array}$} \\
\hline & & \multirow{2}{*}{$\begin{array}{c}\mathbf{F} \\
855\end{array}$} & \multirow{2}{*}{$\begin{array}{c}\% \\
81,4\end{array}$} \\
\hline 1 & How often do you think about COVID-19 & & \\
\hline 2 & How often do you feel paranoid/scared about COVID-19 & 618 & 58,8 \\
\hline 3 & How often do you avoid partying & 939 & 89,3 \\
\hline 4 & How often you avoid direct social contact & 882 & 83,9 \\
\hline 5 & How often you avoid large meetings directly such as worship, meetings, and more & 873 & 83,1 \\
\hline 6 & How often you order food online & 384 & 36,5 \\
\hline 7 & How often do you talk to your friends about the COVID-19 pandemic & 778 & 74,0 \\
\hline 8 & $\begin{array}{l}\text { How often you have trouble sleeping due to worry about the spread and transmission of } \\
\text { COVID-19 }\end{array}$ & 273 & 26,0 \\
\hline 9 & How often you feel affected by news coverage in newspapers and TV & 540 & 51,4 \\
\hline 10 & How often you feel the need to buy and store all the needs at home & 569 & 54,1 \\
\hline 11 & $\begin{array}{l}\text { How often do you feel scared if anyone in your neighborhood is reported to be infected } \\
\text { with COVID-19 }\end{array}$ & 635 & 60,4 \\
\hline 12 & How often you feel you need to use a hand cleanser & 970 & 92,3 \\
\hline 13 & $\begin{array}{l}\text { How often you feel you need to constantly wash your hands using soap or hand } \\
\text { sanitizer }\end{array}$ & 958 & 91,2 \\
\hline 14 & $\begin{array}{l}\text { How often do you feel worried about yourself, and the people closest to the spread and } \\
\text { transmission of the COVID-19? }\end{array}$ & 874 & 83,2 \\
\hline 15 & How often you use masks even without any obvious symptoms of infection & 972 & 92,5 \\
\hline 16 & $\begin{array}{l}\text { How often the story of COVID-19 makes you feel frightened so that it leads to } \\
\text { unnatural behavior towards others }\end{array}$ & 318 & 30,3 \\
\hline 17 & How often are the stories of COVID-19 that make you panic on social media & 321 & 30,5 \\
\hline
\end{tabular}

Source: Primary Data, 2020

Anxiety among study participants on COVID-19 was presented in table 4 . More than $85 \%$ of the participants were busy with a COVID-19 pandemic, around $60 \%$ of the paranoid participants with a mind contracted COVID-19 during a pandemic. About $85 \%$ of participants avoided party, social contact, and avoided meetings such as worship, meetings, and others for fear of being displaced by COVID-19. About $83 \%$ of participants reported worrying for themselves and their closest people during the ongoing pandemic. About $92 \%$ of participants always use masks even without any obvious symptoms of infection.

\section{Discussion}

Indonesia is still not able to suppress the transmission of COVID-19 effectively. The population of Indonesia participates in this study, most of the community has a good knowledge of the spread of COVID-19, which is evident from some of the questions we ask. Respondents to this study who have higher knowledge are also due to most of the respondents over the age of 20. The results of the study were conducted in three countries (Jordan, Saudi Arabia, and Kuwait), that the higher COVID-19 knowledge scores proved to be significantly related to the age and achievement of education. ${ }^{6}$ Knowledge is considered important in the prevention efforts of COVID-19 if society has good knowledge, hopefully, the community is more obedient in the prevention efforts of COVID-19 recommended by the Indonesian Government. The study in China obtained $89 \%$ demonstrated sufficient knowledge about COVID-19. Knowledge is a prerequisite for building preventative beliefs, shaping positive attitudes, and promoting positive behaviors, and individual cognition 
and attitudes towards the disease affect the effectiveness of certain strategies and behaviors. ${ }^{7}$

Participants of this study were optimistic about the prevention of COVID-19, most of the participants took the precaution of spreading the infection by COVID-19, such as: not shaking hands and hug when meeting friends or colleagues, always use masks when exiting the house and wash hands using soap or hand sanitizer regularly. Previous research showed that most of the population took the COVID-19 precautions, i.e. not traveling in crowded places, ${ }^{8}$ and using masks. ${ }^{9}$ Study in Vietnam stated that the prevention of the transmission of COVID-19 was by hand washing and using face masks. ${ }^{10}$

Most of the study participants agreed to be isolated at home if they made a contact or interaction with the COVID-19 infected person. Disconnecting the suggested transmission chain is to implement social distance as well as isolation and quarantine to the general public who have symptoms of COVID-19. The patient's isolation is very effective in stopping the transmission if early detection is possible before a clear virus release. ${ }^{11}$

Findings from this study, often the respondents wash their hands using soap, sanitizer, and mask. This shows the respondent's concern for the action to maintain personal hygiene to avoid the COVID-19 infection. Respondents ' awareness of the COVID-19 was seen in their behavior, as the frequent avoidance of going to the party, avoiding meetings, and also avoid going to the place of worship. Anxiety was also reflected by their fears that there was a COVID-19 transmission, even a quarter of respondents were struggling to sleep because of a COVID-19 spread. The level of anxiety in respondents can cause unnatural behavior such as anxiety, worry, or anger.

Excessive anxiety in society will have an impact on mental life. Therefore, it is important to address the difficulties of mental health in a pandemic situation. Study in India states that when anxiety occurs a broad population, it can lead to panic for the community, which causes the resources to quickly run out. Research in Iraq states that social media has a significant impact on the spread of fear and panic related to the COVID-19 outbreak, with a potential negative influence on mental health and psychological wellbeing of society. ${ }^{12}$

\section{Conclusion}

Our study showed that respondents had a good knowledge of the way the transmission and prevention of COVID-19 had a positive attitude during the pandemic and some respondents felt anxiety during the COVID-19 pandemic. There need to be mental health consulting facilities for the community throughout Indonesia to reduce the level of public anxiety.

\section{Conflict of Interest: Nil.}

\section{Source of Funding: Nil.}

Ethical Clearance: The study was approved by the institutional Ethical Board of Immanuel School of Health Sciences Bandung.

\section{References}

1. Setiati S, Azwar MK. COVID-19 and Indonesia. Acta Med Indones [Internet]. 2020;52(1):84-9. Available from: https://pubmed.ncbi.nlm.nih. gov/32291377/

2. Kim S-W, Su K-P. Using psychoneuroimmunity against COVID-19. Brain Behav Immun [Internet]. 2020; Available from: https://www.sciencedirect. com/science/article/pii/S0889159120303913

3. Ho CSH, Chee CY, Ho RC. Mental health strategies to combat the psychological impact of COVID-19 beyond paranoia and panic. Ann Acad Med Singapore [Internet]. 2020;49(1):1-3. Available from: https://pubmed.ncbi.nlm.nih.gov/32200399/

4. Roy D, Tripathy S, Kar SK, Sharma N, Verma SK, Kaushal V. Study of knowledge, attitude, anxiety $\&$ perceived mental healthcare need in Indian population during COVID-19 pandemic. Asian J Psychiatr [Internet]. 2020;102083. Available from: https://www.sciencedirect.com/science/article/pii/ S1876201820301945

5. Brooks SK, Webster RK, Smith LE, Woodland L, Wessely S, Greenberg N, et al. The psychological impact of quarantine and how to reduce it: rapid review of the evidence. Lancet [Internet]. 2020; Available from: https://www.sciencedirect.com/ science/article/pii/S0140673620304608

6. Naser AY, Dahmash EZ, Alwafi H, Alsairafi ZK, Al Rajeh AM, Alhartani YJ, et al. Knowledge and practices towards COVID-19 during its outbreak: 
a multinational cross-sectional study. medRxiv [Internet]. 2020; Available from: https://www. medrxiv.org/content/10.1101/2020.04.13.2006356 0v1

7. Zhou M, Tang F, Wang Y, Nie H, Zhang L, You $\mathrm{G}$, et al. Knowledge, attitude and practice regarding COVID-19 among health care workers in Henan, China. J Hosp Infect [Internet]. 2020; Available from: https://www.sciencedirect.com/science/ article/pii/S0195670120301870

8. Zhong B-L, Luo W, Li H-M, Zhang Q-Q, Liu X-G, $\mathrm{Li} \mathrm{W}-\mathrm{T}$, et al. Knowledge, attitudes, and practices towards COVID-19 among Chinese residents during the rapid rise period of the COVID-19 outbreak: a quick online cross-sectional survey. Int J Biol Sci [Internet]. 2020;16(10):1745. Available from: https://www.ncbi.nlm.nih.gov/pmc/articles/ PMC7098034/

9. Dkhar SA, Quansar R, Saleem SM, Khan SMS. Knowledge, attitude, and practices related to COVID-19 pandemic among social media users in J \& K, India. Indian J Public Health [Internet]. 2020;64(6):205. Available from: http://www.ijph.
in/article.asp?issn=0019-557X;year=2020; volume $=64 ;$ issue $=6$; spage $=205 ;$ epage $=210$; aulast $=$ Dkhar

10. Huynh G, Nguyen TNH, Vo KN, Pham LA. Knowledge and attitude toward COVID-19 among healthcare workers at District 2 Hospital, Ho Chi Minh City. Asian Pac J Trop Med [Internet]. 2020;13(6):260. Available from: http://www. apjtm.org/article.asp?issn=1995-7645; year=2020; volume $=13$; issue $=6$; spage $=260$; epage $=265$; aulast $=$ Huynh

11. Wilder-SmithA,FreedmanDO.Isolation, quarantine, social distancing and community containment: pivotal role for old-style public health measures in the novel coronavirus $(2019-\mathrm{nCoV})$ outbreak. J Travel Med [Internet]. 2020;27(2):taaa020. Available from: https://academic.oup.com/jtm/ article/27/2/taaa020/5735321

12. Ahmad AR, Murad HR. The impact of social media on panic during the COVID-19 pandemic in Iraqi Kurdistan: online questionnaire study. J Med Internet Res [Internet]. 2020;22(5):e19556. Available from: https://www.jmir.org/2020/5/ e19556/ 